ISSN 0258-7122

Bangladesh J. Agril. Res. 37(4): 593-606, December 2012

\title{
ADOPTION AND PROFITABILITY OF BARI LENTIL VARIETIES IN SOME SELECTED AREAS OF BANGLADESH
}

\author{
M. S. RAHMAN ${ }^{1}$, M. A. HOSSAIN ${ }^{2}$ \\ M. J. U. SARKER ${ }^{3}$ AND M. A. BAKR ${ }^{4}$
}

\begin{abstract}
Lentil is an important pulse crop widely grown in Bangladesh. It ranks first among the pulses in terms of area and consumers' preference. BARI has developed many improved lentil varieties and disseminated to the farmers fields. The up-to-date information regarding adoption and financial profitability of this crop are unknown to the researchers and policymakers. Therefore, the study was conducted in Jhenaidah and Jessore districts to determine the adoption status and profitability of BARI lentil production and to examine the factors affecting the yield of BARI lentil during 2010-2011. Cobb-Douglas production function was used. The study revealed that $98 \%$ of the total lentil cultivated areas were occupied by BARI lentil varieties in the study areas. The average level of adoption of BARI Masur-3, BARI Masur-4, BARI Masur-5 and BARI Masur-6 were $49 \%, 47 \%, 1 \%$ and $1 \%$, respectively at farm level. The cultivation of BARI lentil was profitable to the farmers since the per hectare total cost, gross return and net return of BARI lentil cultivation were Tk 52,734, Tk 80,572 and Tk 27,838, respectively. Functional analysis revealed that seed, urea, mechanical power cost and pesticides had positive effect on the yield of lentil production. Unavailability of latest BARI lentil seed, lack of technical know-how, lack of training, and diseases (root rot and stemphylium blight) were the main constraints to BARI lentil cultivation at farm level. BARI Masur-3 and BARI Masur-4 were the highly adopted varieties. The lentil production was profitable to the farmers in the study areas.
\end{abstract}

Keywords: Adoption, profitability, lentil, Bangladesh.

\section{Introduction}

Pulses are important legume crops in Bangladesh because of their importance in food, feed, and cropping systems. It contains about twice as much protein as cereals. It also contains amino acid lysine which is generally deficient in food grains (Elias et al., 1986). Pulses have played an important role in sustaining the productivity of soils in Bangladesh for centuries. They are generally grown without fertilizer since they can meet their nitrogen requirement by symbiotic fixation of atmospheric nitrogen in the soil (Senanayake et al., 1987; Zapata et al., 1987; Fried and Middleboe, 1977). The per capita consumption of pulse in Bangladesh is only $12 \mathrm{~g} /$ day, which is much lower than WHO recommendation of 45 g/day (Afzal et al., 1999).

\footnotetext{
${ }^{1 \& 3}$ Senior Scientific Officer and Chief Scientific Officer, respectively, On-Farm Research Division, ${ }^{2 \& 4}$ Senior Scientific Officer and Ex-Project Director, respectively, Pulses Research Centre, Bangladesh Agricultural Research Institute(BARI), Gazipur, Bangladesh.
} 
In Bangladesh, lentil placed second position among the pulses according to area and production but stand first in terms of usage (Afzal et al., 1999). It is the principal and popular edible crop among pulses. Lentil grain contains 25\% protein, $0.7 \%$ fat, and 59\% carbohydrate (Afzal et al., 1999). The area, production, and yield of lentil in Bangladesh were 208800 ha, 153000 tons (t), and $0.733 \mathrm{t} / \mathrm{ha}$, respectively, in 1991-92 (BBS, 1995). After 18 years, the area, production, and yield of lentil were $70983 \mathrm{ha}, 60537 \mathrm{t}$, and $0.853 \mathrm{t} / \mathrm{ha}$, respectively, in 2008-09 (BBS, 2009). Thus, it is noted that area and production of lentil decreased 2.94 and 2.53 times, respectively. The area and production of lentil is declining year after year (Table 1).

It is observed in Table 1 that the annual growth rates of lentil area and production decreased significantly in all periods, while the rate of yield increased in all periods due to introduction of new and HYV of lentil. In Pakistan, growth rate trend showed a lower rate of decline for the lentil areas, but a higher rate of increase in yield during 1964-95 (Khan et al., 1988).

Table 1. Area, production, yield of lentil and annual growth rates lentil in Bangladesh during 1991-2008.

\begin{tabular}{lccc}
\hline Year & Area (ha) & Production (t) & Yield (t/ha) \\
\hline $1991-92$ & 208800 & 153000 & 0.733 \\
$1992-93$ & 207800 & 163000 & 0.784 \\
$1993-94$ & 207500 & 167600 & 0.808 \\
$1994-95$ & 207200 & 168000 & 0.811 \\
$1995-96$ & 205868 & 169945 & 0.826 \\
$1996-97$ & 206439 & 170505 & 0.826 \\
$1997-98$ & 205858 & 162775 & 0.791 \\
$1998-99$ & 205577 & 165315 & 0.804 \\
$1999-00$ & 166781 & 127775 & 0.766 \\
$2000-01$ & 164567 & 125905 & 0.765 \\
$2001-02$ & 157229 & 115205 & 0.733 \\
$2002-03$ & 154123 & 115590 & 0.750 \\
$2003-04$ & 154810 & 122225 & 0.790 \\
$2004-05$ & 153899 & 111065 & 0.722 \\
$2005-06$ & 134694 & 115370 & 0.857 \\
$2006-07$ & 137613 & 116810 & 0.849 \\
$2007-08$ & 72613 & 71535 & 0.985 \\
$2008-09$ & 70983 & 60537 & 0.853 \\
Growth rates: & & & \\
$1991-2000$ & $-2.27 * *$ & $-2.19^{*}$ & 0.08 \\
$2001-2008$ & $-11.69^{* * *}$ & $-8.34^{* *}$ & $3.35^{* *}$ \\
$1991-2008$ & $-5.27 * * *$ & $-4.74^{* *}$ & 0.53 \\
\hline
\end{tabular}

Note: Growth rates were calculated by fitting exponential function/a semi-log model $\left(\operatorname{LnY}_{1}=\operatorname{Ln} a+b_{t}\right)$.

***, ** and * indicate significant at $1 \%, 5 \%$ and $10 \%$ level of probability, respectively. Source: Various issues of BBS, 1995, 2000, and 2009. 
Lentil is cultivated in different parts of the country. But it is extensively cultivated in mid-western parts of Bangladesh. The yield of local lentil variety in Bangladesh is very poor, but varied widely between farms and between locations (Sikder and Elias, 1985). The yield of lentil increased with an increase of farm size in India (Tomer et al., 1978). BARI has developed a good number popular varieties of lentil, which is growing in the farmers' fields. But the adoption status and the economic performance of this crop are unknown to the researchers and policymakers. Because, a limited study was done in this line. The rate of adoption and sustainability of any crop depends largely on its economic profitability. Economic viability is one of the important criteria for assessing the suitability of a new crop technology. Therefore, this study is expected to provide valuable information and may be useful to the researchers of BARI as well as the policy makers of both GO and NGOs for formulating appropriate policy for widespread cultivation of lentil in Bangladesh. With this view in mind, the study was undertaken to the following objectives:

\section{Objectives}

i. To estimate the area covered by the lentil varieties;

ii. To know the adoption status of BARI lentil varieties at farm level;

iii. To estimate the profitability of the BARI lentil;

iv. To examine the factors affecting the yield of lentil; and

v. To find out the constraints to BARI lentil cultivation.

\section{Materials and Method}

Sampling design: A multi-stages sampling procedure was followed to select study areas and sample households. At first, two lentil growing Upazillas, namely Kaliganj from Jhenaidah and Chaugachha from Jessore district were purposively selected for the study. Secondly, two villages, namely Perojpur and Jagodispur were purposively selected from Kaliganj and Chaugachha upazilla, respectively, for household survey. Finally, a list of lentil growers was constructed for each village and then a total of 120 samples taking 60 samples from each village list were randomly selected for data collection.

Data collection procedure: Data for the present study were collected by interviewing sample lentil growers using a pre-tested interview schedule during the period from March to May 2011. Secondary data were also collected from Directorate of Agricultural Extension to supplement the study.

Analytical techniques: The collected data were analyzed by tabular and statistical methods. The profitability of lentil cultivation was examined on the basis of gross margin, net return, and rate of return over cost. BARI lentil varieties cultivated by farmers were classified into four categories for 
determining the adoption level of technologies in terms of agronomic practices, time of operation, and input use. The categories were developed based on the mean index of the farmers with respect to each technology. A higher index indicates a higher level of adoption, while a lower index indicates a lower level of adoption of a technology. Technology adoption level was categorized for mean index $>100$ as over use; (70-100) as high; (50-69) as medium and $<50$ as low (Miah and Alam, 2008). Adoption index was determined by the following formula.

$$
\text { Adoption index }=\frac{\text { Farmers' practice }}{\text { Recommendation }} \times 100
$$

Cobb-Douglas production function was used to estimate the contribution of factors influencing the productivity of lentil. The functional form of the CobbDouglas model is given below:

$$
Y=A X_{1}^{b 1} X_{2}^{b 2} \ldots \ldots \ldots X_{n}^{b n} e^{u i}
$$

The production function was converted to logarithmic form so that it could be solved by least square method i.e,

$$
\log Y=\log a+b_{1} \log X_{1}+\ldots . .+b_{n} \log _{n}+U_{i}
$$

The empirical production function was as follows:

$$
\begin{aligned}
& \mathrm{LnY}=\mathrm{a}^{+}{ }_{1} \ln \mathrm{X}_{1}+\mathrm{b}_{2} \ln \mathrm{X}_{2}+\mathrm{b}_{3} \ln \mathrm{X}_{3}+\mathrm{b}_{4} \ln \mathrm{X}_{4}+\mathrm{b}_{5} \ln \mathrm{X}_{5}+\mathrm{b}_{6} \ln \mathrm{X}_{6}+\mathrm{b}_{7} \ln \mathrm{X}_{7}+\mathrm{b}_{8} \ln \mathrm{X}_{8}+\mathrm{U}_{\mathrm{i}} \\
& \text { Where, } \\
& \begin{array}{ll}
\mathrm{Y}=\text { Yield (kg/ha) } & \mathrm{X}_{6}=\operatorname{MoP}(\mathrm{kg} / \mathrm{ha}) \\
\mathrm{X}_{1}=\text { Human labour (man-days/ha) } & \mathrm{X}_{7}=\operatorname{Gypsum}(\mathrm{kg} / \mathrm{ha}) \\
\mathrm{X}_{2}=\text { Mechanical power cost (Tk./ha) } & \mathrm{X}_{8}=\text { Pesticides (Tk./ha) } \\
\mathrm{X}_{3}=\text { Seed }(\mathrm{kg} / \mathrm{ha}) & \mathrm{a}=\text { Intercept } \\
\mathrm{X}_{4}=\text { Urea }(\mathrm{kg} / \mathrm{ha}) & \mathrm{b}_{1}, \mathrm{~b}_{2}, \ldots \mathrm{b}_{\mathrm{n}}=\text { Coefficients of the } \\
\mathrm{X}_{5}=\text { TSP }(\mathrm{kg} / \mathrm{ha}) & \text { respective variables to be estimated. } \\
& \text { Ui }=\text { Error term }
\end{array}
\end{aligned}
$$

\section{Results and Discussion}

\section{Farm size of the sample farmers}

The average farm size of the sample farmers was 1.72 ha in the study areas. The farm size of Kaliganj farmers was higher (2.08 ha) compared to Chaugachha farmers (1.36 ha). The average lentil cultivated area was found to be 0.51 ha in which about one hundred percent area was occupied by BARI lentil varieties. That is why, the lentil cultivated area and BARI lentil varieties areas were found to be same and it was 0.80 ha at Kaliganj and 0.21 ha at Chaugachha (Table 2). 
Table 2. Farm size of lentil farmers in the study areas.

\begin{tabular}{lcc|c}
\hline \multicolumn{1}{c|}{ Particulars } & Kaliganj & Chaugachha & All area \\
\hline Farm size (ha) & 2.08 & 1.36 & 1.72 \\
$\begin{array}{l}\text { Lentil cultivated area (ha) } \\
\begin{array}{l}\text { BARI lentil varieties cultivated } \\
\text { area (ha) }\end{array}\end{array}$ & 0.80 & 0.22 & 0.51 \\
\hline
\end{tabular}

Source: Field Survey, 2011.

\section{Area coverage by BARI lentil varieties at district level}

Department of Agriculture Extension (DAE) reported that 8875 ha of land was cultivated with lentil in Jhenaidah district in 2009-2010 in which $80 \%$ areas were covered by BARI lentil varieties and $20 \%$ by local variety. In Jessore area, 9340 ha of land was devoted to lentil cultivation in which $76 \%$ areas were sown by BARI lentil varieties and $24 \%$ by local variety. On an average, $78 \%$ areas were occupied by BARI lentil varieties in the study areas (Table 3).

The level of adoption of BARI Masur-2, BARI Masur-3, BARI Masur-4, BARI Masur-5, and BARI Masur-6 were $8 \%, 20 \%, 38 \%, 31 \%$, and $3 \%$, respectively (Table 4). In Jhenaidah, BARI Masur-4 covered the highest areas (45\%) followed by BARI Masur-5 (38\%), BARI Masur-3 (10\%), BARI Masur-2 (5\%), and BARI Masur-6 (2\%). In Jessore, BARI Masur-4 and BARI Masur-3 covered the same area (30\%) and it was followed by BARI Masur-5 (25\%), BARI Masur-2 (10\%) and BARI Masur-6 (5\%).

Table 3. Area under BARI lentil varieties cultivation during 2009-2010.

\begin{tabular}{l|c|c|c}
\hline Study area & $\begin{array}{c}\text { Total Lentil area } \\
\text { (ha) }\end{array}$ & $\begin{array}{c}\text { Area under BARI lentil } \\
\text { varieties (ha) }\end{array}$ & $\begin{array}{c}\text { Area under local } \\
\text { variety (ha) }\end{array}$ \\
\hline Jhenaidah & $8875(100)$ & $7100(80)$ & $1775(20)$ \\
Jessore & $9340(100)$ & $7098(76)$ & $2242(24)$ \\
Both areas & $18215(100)$ & $14198(78)$ & $4017(22)$
\end{tabular}

Source: DAE, 2010

Table 4. Adoption scenario of BARI lentil varieties.

\begin{tabular}{l|c|c|c|c|c|c}
\hline $\begin{array}{c}\text { Study } \\
\text { area }\end{array}$ & $\begin{array}{c}\text { BARI } \\
\text { Masur-2 } \\
(\%)\end{array}$ & $\begin{array}{c}\text { BARI } \\
\text { Masur-3 } \\
(\%)\end{array}$ & $\begin{array}{c}\text { BARI } \\
\text { Masur-4 } \\
(\%)\end{array}$ & $\begin{array}{c}\text { BARI } \\
\text { Masur-5 } \\
(\%)\end{array}$ & $\begin{array}{c}\text { BARI } \\
\text { Masur-6 } \\
(\%)\end{array}$ & $\begin{array}{c}\text { Total } \\
(\%)\end{array}$ \\
\hline Jhenaidah & 05 & 10 & 45 & 38 & 02 & 100 \\
Jessore & 10 & 30 & 30 & 25 & 05 & 100 \\
All Areas & 08 & 20 & 38 & 31 & 03 & 100 \\
\hline
\end{tabular}

Source: DAE, 2010 


\section{Area coverage by BARI lentil varieties at farm level}

One hundred percent lentil cultivated areas of the sample farmers were occupied by BARI released different lentil varieties at Kaliganj area, whereas 95\% areas were sown by BARI lentil varieties at Chaugachha area (Table 5). On an average, 98\% lentil cultivated areas were sown by BARI released different lentil varieties in all areas and the rest areas were used by local variety. It is evident that BARI Masur-3 and BARI Masur-4 were the highly adopted varieties in the study areas.

Table 5. Distribution of lentil cultivated areas by BARI released lentil varieties.

\begin{tabular}{l|c|c|c|c|c|c}
\hline Study areas & \multirow{2}{*}{$\begin{array}{c}\text { Lentil } \\
\text { cultivate }\end{array}$} & \multicolumn{5}{|c}{ Percent of lentil cultivated area } \\
\cline { 3 - 7 } & $\begin{array}{c}\text { d areas } \\
\text { (ha) }\end{array}$ & $\begin{array}{c}\text { BARI } \\
\text { Masur-3 }\end{array}$ & $\begin{array}{c}\text { BARI } \\
\text { Masur-4 }\end{array}$ & $\begin{array}{c}\text { BARI } \\
\text { Masur-5 }\end{array}$ & $\begin{array}{c}\text { BARI } \\
\text { Masur-6 }\end{array}$ & $\begin{array}{c}\text { Local } \\
\text { variety }\end{array}$ \\
\hline Kaliganj & 0.80 & 6 & 90 & 2 & 2 & 0 \\
Chaugachha & 0.22 & 92 & 3 & 0 & 0 & 5 \\
All Areas & 0.51 & 49 & 47 & 1 & 1 & 2 \\
\hline
\end{tabular}

Source: Field Survey, 2011.

\section{Technology used and their level of adoption}

Appropriate inputs use and time of operations are essential for achieving higher yield and economic benefit. Therefore, it is important to know the existing level of technology in terms of agronomic practices, time of operation, and input use. The existing level of technology employed in the production of BARI lentil and their level of adoption have been presented in Table 6 .

Farmers in the study areas ploughed their lentil lands with the help of power tiller and tractor. The number of ploughings and ladderings varied from farm to farm and location to location. On an average, 70\% farmers ploughed their land 34 times, which is the recommended for lentil cultivation. Based on the mean index, land preparation secured the over use level of adoption. About 91\% farmers applied laddering 2-3 times, which was lower than recommendation. Laddering secured medium level of adoption.

Farmers in the study areas followed broadcast method for lentil seed sowing. It was started from the third week of October and continued up to the $1^{\text {st }}$ week of December. About 50\% farmer's sowed seeds during last week of October to first week of November which is optimum time for seed sowing. Whereas $47 \%$ farmers sowed during second week of November to $1^{\text {st }}$ week of December. At Kaliganj, 93\% farmers sowed seed in optimum time but only 6\% Chaugachha farmers followed it. The time of seed sowing was highly adopted at Kaliganj because farmers found it convenient to sow during the available range of time. 
The recommended seed rate of BARI lentil ranged $35-40 \mathrm{~kg} / \mathrm{ha}$. All respondent farmers used higher amount of seed (30\% higher) than its recommendation. Therefore, the level of adoption of seed rate was found to be over used.

Weeding was done by human labour. Fifty percent of the total farmers performed weeding once between 20 and 30 days after emergence (DAE) of seed. At Kaliganj, all farmers weeded their land one time, while Chaugachha farmers did not remove weed. The higher level of adoption was occurred in providing weeding to HYV lentil crop at Kaliganj. The study found that farmers often do not follow recommendations for applying fertilizers. They tended to either use fertilizers in excess or in very small quantities. All the sample farmers applied urea, TSP, and MoP in higher quantity compared to their recommended doses. Therefore, according to adoption index, the level of adoption for applying fertilizer is over use.

Table 6. Adoption of crop management technologies for BARI lentil production at farm level.

\begin{tabular}{|c|c|c|c|c|c|}
\hline Technology & $\begin{array}{l}\text { Recomm- } \\
\text { endation }\end{array}$ & Kaliganj & Chaugachha & $\begin{array}{c}\text { All } \\
\text { areas }\end{array}$ & $\begin{array}{l}\text { Adoption } \\
\text { level }\end{array}$ \\
\hline \multicolumn{5}{|l|}{$\begin{array}{l}\text { 1. No. of ploughing (\% of } \\
\text { respondents ) }\end{array}$} & Over use \\
\hline $3-4$ & Optimum & 67 & 72 & 70 & \\
\hline $5-6$ & & 33 & 28 & 30 & \\
\hline Adoption index & & 110 & 108 & 109 & \\
\hline \multicolumn{5}{|l|}{$\begin{array}{l}\text { 2. Laddering (\% of } \\
\text { respondents) }\end{array}$} & Medium \\
\hline $2-3$ & & 87 & 94 & 91 & \\
\hline $4-5$ & Optimum & 13 & 06 & 09 & \\
\hline Adoption index & & 55 & 46 & 51 & \\
\hline \multicolumn{5}{|l|}{$\begin{array}{l}\text { 3. Sowing time (\% of } \\
\text { respondents) }\end{array}$} & High \\
\hline Third week of October & & 07 & & 03 & \\
\hline $\begin{array}{l}\text { Last week of October - } \\
\text { First week of November }\end{array}$ & Optimum & 93 & 06 & 50 & \\
\hline $\begin{array}{l}2^{\text {nd }} \text { week of November } \\
-1^{\text {st }} \text { week of December }\end{array}$ & & - & 94 & 47 & \\
\hline Adoption index & & 97 & 53 & 75 & \\
\hline
\end{tabular}


Table 6. Cont'd.

\begin{tabular}{l|c|c|c|r|c}
\hline Technology & $\begin{array}{c}\text { Recommen } \\
\text { dation }\end{array}$ & Kaliganj & Chaugachha & $\begin{array}{r}\text { All } \\
\text { areas }\end{array}$ & $\begin{array}{c}\text { Adoption } \\
\text { level }\end{array}$ \\
\hline 4. Seed rate (kg/ha) & $35-40$ & 48 & 55 & 52 & Over use \\
$\quad$ Adoption index & & 121 & 137 & 129 & \\
5. No. of weeding (\% of & & & & & Medium \\
respondent) & & & & & \\
One time (20-30 days & Optimum & 100 & 0 & 50 & \\
after germination) & & & & & \\
Adoption index & & 100 & 0 & 50 & \\
6. Fertilizer dose (kg/ha) & & & & & \\
Urea & 45 & 63 & 60 & 62 & Over use \\
Adoption index & & 139 & 133 & 136 & \\
TSP & 85 & 124 & 77 & 101 & Over use \\
Adoption index & & 146 & 91 & 119 & \\
MoP & 35 & 69 & 23 & 46 & Over use \\
Adoption index & & 198 & 67 & 133 & \\
Gypsum & & 37 & 0 & 37 & \\
\hline
\end{tabular}

Note: Adoption level was categorized for mean index > 100 as Over use; (70-100) as High; (50-69) as medium and $<50$ as low.

Source: Field Survey, 2011.

\section{Input use pattern of BARI lentil cultivation}

Human labour was measured in terms of man-day, which usually consisted of 8 hours. It was employed for land preparation, fertilizing, weeding, pesticiding, harvesting, threshing, and drying. The total number of human labour used for lentil cultivation was 94 man-days/ha (Table 7). The farmers of Kaliganj area used more human labour (110 mandays/ha) compared to the farmers of Chaugachha area (77 mandays/ha) due to more labour use in weeding and spraying pesticides. They used lentil seeds at the rate of $52 \mathrm{~kg} / \mathrm{ha}$. Chaugachha farmers used more quantity of seed (55 kg/ha) compared to Kaliganj farmers (48 $\mathrm{kg} / \mathrm{ha}$ ), which was higher than recommendation. The application of urea, TSP, MoP, and gypsum per hectare were $62 \mathrm{~kg}, 101 \mathrm{~kg}, 46 \mathrm{~kg}$, and $19 \mathrm{~kg}$, respectively, in all study areas which were also higher than recommendation except gypsum. It is evident that all inputs used at Kaliganj area were higher than that of Chaugachha area.

\section{Profitability level of BARI lentil cultivation}

The cost of cultivation was calculated on the basis of total variable cost and total cost. The average cost of BARI lentil production was estimated at Tk. 52734/ha and Tk. 33191/ha, respectively, on the basis of total cost and total variable cost (Table 7). The cost of lentil production at Kaliganj area was higher than that of 
Chaugachha area due to more cost spent by Kaliganj farmers almost in all items except seed and land use. It is evident from Table 8 that the average grain yield of BARI lentil varieties was $1733 \mathrm{~kg} / \mathrm{ha}$ in all areas. The grain yield was higher at Kaliganj (1871 kg/ha) compared to Chaugachha (1595 kg/ha) due to higher input use. On an average, gross return was found to be Tk. 80572/ha in all study areas. Table 8 revealed that gross return at Kaliganj was higher (Tk. 85958/ha) than that of Chaugachha (Tk. 75186/ha). The average gross margin of BARI lentil was estimated at Tk. 47381/ha in all areas. Gross margin at Chaugachha was higher than that of Kaliganj. The net return of BARI lentil was calculated Tk. 27838/ha in all areas. The net return at Kaliganj was higher than that of Chaugachha. Benefit cost ratio was found to be 1.53 on total cost basis in all areas. BCR at Chaugachha was higher than that of Kaliganj.

Table 7. Input use pattern and cost of BARI lentil production at farm level.

\begin{tabular}{l|rr|r|r|r|r}
\hline \multirow{2}{*}{ Cost Items } & \multicolumn{2}{c|}{ Kaliganj } & \multicolumn{2}{c|}{ Chaugachha } & \multicolumn{2}{c}{ All Areas } \\
\cline { 2 - 7 } & Quantity & (Tk./ha) & Quantity & (Tk./ha) & Quantity & (Tk./ha) \\
\hline Labour ( manday/ha) & 110 & 16526 & 77 & 11477 & 94 & 14002 \\
Mechanical power cost (Tk/ha) & 6356 & 9913 & 6055 & 7758 & 6206 & 8836 \\
Seed (kg/ha) & 48 & 4197 & 55 & 4300 & 52 & 4249 \\
Fertilizers: & - & 4735 & - & 2764 & - & 3749 \\
Urea (kg/ha) & 63 & 751 & 60 & 711 & 62 & 731 \\
TSP (kg/ha) & 124 & 2752 & 77 & 1658 & 101 & 2205 \\
MoP (kg/ha) & 69 & 1041 & 23 & 349 & 46 & 695 \\
Gypsum (kg/ha) & 37 & 190 & - & - & 19 & 95 \\
Insecticides (Tk/ha) & 4711 & 4711 & - & - & 2356 & 2355 \\
Intt. on operating capital & - & 401 & - & 263 & - & 332 \\
Land use cost & - & 17028 & - & 21394 & - & 19211 \\
Total variable cost & - & 40082 & - & 26299 & - & 33191 \\
Total cost & - & 57511 & - & 47956 & - & 52734 \\
\hline
\end{tabular}

Source: Field Survey, 2011.

Table 8. Productivity and profitability of BARI lentil production at farm level.

\begin{tabular}{lcc|c}
\hline \multicolumn{1}{c|}{ Items } & Kaliganj & Chaugachha & All Areas \\
\hline Yield (kg/ha) & 1871 & 1595 & 1733 \\
Gross return (Tk./ha) & 85958 & 75186 & 80572 \\
Total variable cost (Tk./ha) & 40082 & 26299 & 33191 \\
Total cost (Tk./ha) & 57511 & 47956 & 52734 \\
Gross margin (Tk/ha) & 45876 & 48886 & 47381 \\
Net return (Tk./ha) & 28447 & 27229 & 27838 \\
Benefit cost ratio (undiscounted) & 1.49 & 1.57 & 1.53 \\
\hline
\end{tabular}

Source: Field Survey, 2011. 


\section{Input output relationship}

In order to determine the contribution of independent variables in lentil production, Cobb-Douglas production function was used. Before going to analyze data, multi-collinearity among the variables was checked and found no multi-collinearity in the data. Table 9 shows that the coefficients of seed, urea and pesticides were positive and significant at $1 \%$ level, which indicated that $1 \%$ increases in those inputs keeping other factors remaining constant would increase the yield by $0.223 \%, 0.141 \%$ and $0.021 \%$, respectively. It implied that seed, urea and pesticides had positive effect on the yield of lentil production. The coefficient of mechanical power cost was positive and significant at $10 \%$ level indicating that $1 \%$ increases in the use of mechanical power cost, keeping other factors remaining constant would increase the yield by $0.102 \%$. The coefficient of gypsum was negative and significant at 5\% level, which indicated that $1 \%$ increases of gypsum, keeping other factors remaining constant would decrease the yield by $0.025 \%$. The returns to scale of lentil production were the summation of regression coefficients of all inputs in this study. It is noted from Table 9 that the returns to scale of lentil was 0.48. This implied that production function exhibited decreasing return to scale and lied on the second stage of production. This also implied that if all inputs specified in the production function were increased simultaneously by $100 \%$, the yield would increase by $48 \%$.

Table 9. Estimated coefficients and related statistics of Cobb-Douglas production function for BARI lentil production.

\begin{tabular}{lcccc}
\hline Explanatory variables & Coefficients & Standard error & t-values \\
\hline Constant & $4.970^{* * *}$ & 0.524 & 9.489 \\
Human labour & -0.016 & 0.061 & -0.269 \\
Mechanical power cost & $0.102^{*}$ & 0.057 & 1.784 \\
Seed & $0.223^{* * *}$ & 0.075 & 3.104 \\
Urea & $0.141^{* * *}$ & 0.033 & 4.274 \\
TSP & 0.023 & 0.016 & 1.432 \\
MoP & 0.011 & 0.008 & 1.363 \\
Gypsum & $-0.025^{* *}$ & 0.009 & -2.767 \\
Pesticides & $0.021^{* * *}$ & 0.004 & 4.987 \\
Returns to scale (RTS) & 0.48 & & \\
R & 0.80 & & \\
F-value & $14.613^{* * *}$ & & \\
\hline
\end{tabular}

Note: ***, ** and * indicate significant at $1 \%, 5 \%$ and $10 \%$ level, respectively. 


\section{Farmer's opinions towards BARI lentil production}

Farmers were very much pleased to cultivate modern varieties of lentil because these varieties were high yielder, profitable, and easy to produce. It was lesser infested by insect pest and lesser attacked by disease compared to local variety of lentil (Table 10).

Table 10. Farmers' opinions regarding BARI lentil production.

\begin{tabular}{l|c|c|c}
\hline \multirow{2}{*}{ Opinion } & \multicolumn{3}{c}{ Percent of responses } \\
\cline { 2 - 4 } & Kaliganj & Chaugachha & All area \\
\hline 1. High yielder & 100 & 100 & 100 \\
2. Profitable crop & 100 & 100 & 100 \\
3. Easy to produce & 90 & 86 & 88 \\
4. Lesser pest infestation and disease attack & 60 & 70 & 65 \\
\hline
\end{tabular}

Source: Field Survey, 2011.

\section{Constraints to BARI lentil production at farm level}

The farmers in the study areas encountered some constraints to BARI lentil production. The first ranked constraint was unavailability of latest BARI lentil varieties' seeds in all areas. It is followed by unknown about latest BARI lentil varieties, lack of technical know-how, and lack of training, attack of diseases (root rot, leaf spot and stemphylium blight), high price of pesticides, slightly low price, and less taste compared to local variety lentil (Table 11).

Table 11. Constraint to BARI lentil production at farm level.

\begin{tabular}{l|c|c|c}
\hline \multicolumn{1}{c|}{ Constraints } & \multicolumn{3}{c}{ Rank value } \\
\cline { 2 - 4 } & Kaliganj & Chaugachha & $\begin{array}{c}\text { All } \\
\text { Areas }\end{array}$ \\
\hline 1. Unavailability of latest BARI lentil varieties seed & 1 & 1 & 1 \\
2. Unknown about latest BARI lentil varieties & 2 & 2 & 2 \\
3. Lack of technical know-how & 3 & 3 & 3 \\
4. Lack of training & 4 & 4 & 4 \\
5. Attack of diseases & 5 & 5 & 5 \\
6. High price of pesticides & 6 & 6 & 6 \\
7. Lower price and less taste compared to local & 7 & 7 & 7 \\
\hline
\end{tabular}

Source: Field Survey, 2011. 


\section{Facilities needed for increasing BARI lentil production}

Lentil farmers in the study areas encountered some constraints to BARI lentil production. They used improved seeds of different lentil verities which were developed by BARI and disseminated for farm level use for some years back. In the mean time, six improved lentil varieties have already been released for farmers' use. But these latest varieties are not available to them. Therefore, all the respondent farmers demanded for making those latest lentil varieties available to their nearest local seed market (Table 12). Technical know-how about the improved production technology is very much important for efficient use of inputs and receiving higher yield. Most respondent lentil farmers did not get expected yield due to apply traditional knowledge in producing lentil. Therefore, they need hand-on training on lentil production. Biotic stress is another important constraint to lentil cultivation for which they can't harvest good yield. They opined that some of their used varieties were susceptible to disease. This problem was reported in Kaliganj higher than that of Chaugachha. Hence, most of the respondent farmers suggested developing disease resistant variety for them.

Table 12. Facilities demanded by farmers regarding BARI lentil cultivation.

\begin{tabular}{l|c|c|c}
\hline \multirow{2}{*}{ Type of facility } & \multicolumn{3}{|c}{ Percent of responses } \\
\cline { 2 - 4 } & Kaliganj & Chaugachha & All area \\
\hline $\begin{array}{l}\text { 1. Availability of latest BARI lentil varieties } \\
\quad \text { seed }\end{array}$ & 100 & 100 & 100 \\
$\begin{array}{l}\text { 2. Providing training about lentil production } \\
\text { 3. Development of disease resistant lentil } \\
\quad \text { variety }\end{array}$ & 100 & 100 & 100 \\
\hline
\end{tabular}

Source: Field Survey, 2011.

\section{Conclusion and Recommendations}

Based on the findings of the study, it may be concluded that the highly adopted varieties were BARI Masur-3 and BARI Masur-4. About 98\% lands were occupied by BARI lentil varieties. BARI has developed some new varieties which are better in all respect to them. So, popularization of BARI Masur-5 and BARI Masur-6 is needed and farmers should be motivated accordingly.

Majority of the farmers did not get desired yield for ignoring the recommended use of inputs. So, formal and hand-on training and demonstration on modern method of producing BARI lentil should be imparted to the farmers.

The gross margin and net return of BARI lentil cultivation were positive and encouraging to the farmers. This message should be circulated among the growers through various media. 
The influence of seed, urea, mechanical power cost, and pesticides in lentil production were positively significant. Inadequate use of inputs impedes the effectiveness of other inputs which causes low yield. So, farmers must learn proper use of inputs in time. They should follow recommended practices accurately.

Lentil farmers could not receive higher benefit from lentil cultivation due to various constraints. These constraints were unavailability of latest BARI lentil variety seed, unknown about latest BARI lentil varieties, lack of technical knowhow, lack of training and attack of diseases. Therefore, necessary steps should be taken to make disease resistant BARI lentil seed available to the farmers. Nonetheless, lentil farmers should also be provided hand-on training on package technology of lentil cultivation.

\section{References}

Afzal, M. A., M. A. Bakr and M. L. Rahman. 1999. Lentil cultivation in Bangladesh. Lentil, Blackgram and Mungbean Development Pilot Project, Pulses Research Station, BARI, Gazipur-1701.

BBS. 1995. Yearbook of Agricultural Statistics of Bangladesh. Bangladesh Bureau of Statistics, Ministry of Planning, Government of the People's Republic of Bangladesh, Dhaka.

BBS. 2000. Yearbook of Agricultural Statistics of Bangladesh. Bangladesh Bureau of Statistics, Ministry of Planning, Government of the People's Republic of Bangladesh, Dhaka.

BBS. 2009. Yearbook of Agricultural Statistics of Bangladesh. Bangladesh Bureau of Statistics, Ministry of Planning, Government of the People's Republic of Bangladesh, Dhaka.

Elias. S.M., M.S. Hossain, F.S. Sikder, Juber Ahmed and M. Rezaul Karim. 1986. Identification of constraints to pulse production with special reference to present farming systems. Annual Report of the Agricultural Economic Division, BARI, Joydebpur. p-1.

Fried, M and V. Middelboe. 1977. Measurement of amount of nitrogen fixed by legume crop. Plant and Soil 47: 713-715.

Khan, N. A., M. I. Khan and Q. T. Azam. 1988. Inter-regional analysis of farmers supply response of gram and lentils acreage. Pakistan Journal of Agricultural Development 9(2): 233-240.

Miah, M. A. M. and Q. M. Alam. 2008. Adoption and relative profitability of mustard production in Bangladesh. Annual Report of the Agricultural Economic Division. BARI, Joydebpur. Gazipur. Pp: 38-53.

Senanayake. L., D.P. Knievel, S.E. Stevena. 1987. Nodulation and symbiotic nitrogen fixation of cowpea (Vigna unguiculata L.). Plant Soil 99: 435-439.

Sikder, F.S and S.M. Elias. 1985. An economic assessment of gentil cultivation in some selected areas of Bangladesh. Economic Affairs, India 30(3): 181-186. 
Tomer, R.S., J.P. Bhatia and R. Swarup. 1978. Crop productivity and marketable surplus in paonta valley of Himachal pradesh. Agricultural Situation in India 33(1):9-15.

Zapata. F., S.K.A. Danso, G. Hardarson. M. Fried. 1987. Nitrogen fixation and translocation in field-grown fababean. Agronomy Journal 79: 505-509. 